\title{
Enzymatic characterization of a recombinant carbonyl reductase from Acetobacter sp. CCTCC M209061
}

Ping Wei ${ }^{1,2}$, Yu-Han Cui ${ }^{1}$, Min-Hua Zong ${ }^{1,2}$, Pei Xu' ${ }^{1}$, Jian Zhou ${ }^{2}$ and Wen-Yong Lou ${ }^{1 *}$ (e)

\begin{abstract}
Background: Acetobacter sp. CCTCC M209061 could catalyze carbonyl compounds to chiral alcohols following antiPrelog rule with excellent enantioselectivity. Therefore, the enzymatic characterization of carbonyl reductase (CR) from Acetobacter sp. CCTCC M209061 needs to be investigated.

Results: A CR from Acetobacter sp. CCTCC M209061 (ACCR) was cloned and expressed in E. coli. AcCR was purified and characterized, finding that AcCR as a dual coenzyme-dependent short-chain dehydrogenase/reductase (SDR) was more preferred to $\mathrm{NADH}$ for biocatalytic reactions. The AcCR was activated and stable when the temperature was under $35^{\circ} \mathrm{C}$ and the $\mathrm{pH}$ range was from 6.0 to 8.0 for the reduction of $4^{\prime}$-chloroacetophenone with NADH as coenzyme, and the optimal temperature and $\mathrm{pH}$ were $45^{\circ} \mathrm{C}$ and 8.5 , respectively, for the oxidation reaction of isopropanol with $\mathrm{NAD}^{+}$. The enzyme showed moderate thermostability with half-lives of $25.75 \mathrm{~h}$ at $35^{\circ} \mathrm{C}$ and $13.93 \mathrm{~h}$ at $45^{\circ} \mathrm{C}$, respectively. Moreover, the AcCR has broad substrate specificity to a range of ketones and ketoesters, and could catalyze to produce chiral alcohol with e.e. $>99 \%$ for the majority of tested substrates following the anti-Prelog rule.
\end{abstract}

Conclusions: The recombinant AcCR exhibited excellent enantioselectivity, broad substrate spectrum, and highly stereoselective anti-Prelog reduction of prochiral ketones. These results suggest that AcCR is a powerful catalyst for the production of anti-Prelog alcohols.

Keywords: Carbonyl reductase, Acetobacter sp., Chiral alcohols, Enzymatic characterization

\section{Background}

Chiral alcohols are vitally important building blocks for the synthesis of pharmaceuticals, agricultural chemicals, flavors, and special materials. Currently, both chemical and biological methods can be used to synthesize chiral alcohols. The most prospective biocatalytic method is the asymmetric transfer of hydrogenation to carbonyl groups catalyzed by reductases or microbial cells containing relevant reductases (Li et al. 2014; Zheng et al. 2017). In recent years, the efficient asymmetric reduction of ketones using biocatalysts as its high yield and excellent enantiomeric excess has been extensively used for the

\footnotetext{
*Correspondence: wylou@scut.edu.cn

${ }^{1}$ Lab of Applied Biocatalysis, School of Food Science and Engineering, South China University of Technology, Guangzhou 510640, Guangdong, China

Full list of author information is available at the end of the article
}

production of chiral alcohols in the chemical and pharmaceutical industries (Birolli et al. 2015; Gutierrez et al. 2010).

Carbonyl reductase (CR) or alcohol dehydrogenase $(\mathrm{ADH})$ is $\mathrm{NAD}(\mathrm{P}) \mathrm{H}$-dependent oxidoreductase which can catalyze a variety of carbonyl compounds to the corresponding alcohols (Kaluzna et al. 2005). Enantioselective CRs or ADHs have been reported from animals (Nakajin et al. 1998; Montfort et al. 2002), plants (Sengupta et al. 2015), and microorganisms (Grosch et al. 2015; Singh et al. 2009). A number of CRs or ADHs have been utilized for asymmetrically reducing carbonyl functionalities, and many excellent biocatalytic processes have been developed ( $\mathrm{Li}$ et al. 2015). Among all the sources of CRs, microorganisms are the most important providers, and some CRs or ADHs from microorganisms have been reported with high yield and enantioselectivity 
(Musa and Phillips 2011). The carbonyl reductase SCRII from Candida parapsilosis could catalyze the asymmetric reduction of 2-hydroxyacetophenone to $(S)$-1-phenyl1,2-ethanediol with optical purity of $100 \%$ in high yield of 98.1\% (Zhang et al. 2011). Xu et al. (2015) found that an NADPH-dependent carbonyl reductase from Yarrowia lipolytica ACA-DC 50109 could efficiently convert $\alpha$-chloroacetophenone to $(R)$-2-chloro-1-phenylethol with $99 \%$ e.e. $\mathrm{Ni}$ et al. (2011) heterologously overexpressed a $\beta$-ketoacyl-ACP reductase from Bacillus sp. ECU0013 in E. coli, which was used for efficient reduction of ethyl 2-oxo-4-phenylbutyrate at $620 \mathrm{~g} / \mathrm{L}$, and the e.e. of the product ethyl (S)-2-hydroxy-4-phenylbutyrate was excellent $(>99 \%)$. Therefore, using carbonyl reductases to catalyze the asymmetric reduction of prochiral carbonyl compounds is an efficient and useful method for the synthesis of chiral alcohols (He et al. 2016; Cui et al. 2017; Qian et al. 2014).

The oxidoreductase from Acetobacter is mostly used to produce acetic acid, and rarely used to asymmetric reduction of carbonyl compounds to chiral alcohols. In our previous study, it was found that Acetobacter sp. CCTCC M209061 could catalyze the asymmetric reductions of several carbonyl compounds to corresponding chiral alcohols following anti-Prelog rule with excellent enantioselectivity (Cheng et al. 2014; Wei et al. 2015, 2016). In the present work, the AcCR was heterologously expressed and systematically characterized for its substrate spectrum, stereoselectivity, and the capacity of industrial application.

\section{Methods}

\section{Chemicals, bacterial strains, and plasmids}

The Acetobacter sp. CCTCC M209061 strain was previously isolated by our group from Chinese kefir grains and stored at $-80{ }^{\circ} \mathrm{C}$. E. coli DH5 $\alpha$, BL21(DE3)pLysS, and plasmid pGEX-2T were purchased from Novagen. The restriction enzyme FastDigest AvaI, EcoRI, T4 DNA Ligase, DNA, and protein marker were purchased from Thermo Scientific. KOD FX polymerase for PCR was purchased from Toyobo. The kits used in the construction of the recombinant plasmids were purchased from Generay. The prochiral ketones were purchased from Sigma Aldrich or Aladdin. The primers synthesis and DNA sequencing were completed by Sangon Biotech. All other reagents and solvents were of analytical grade and used without further purification.

\section{Expression of AcCR in E. coli BL21(DE3)pLysS} Genomic DNA of Acetobacter sp. CCTCC M209061 was extracted and purified using a bacterial genomic DNA Kit. Oligonucleotide primers for accr were designed according to the published gene sequence of oxidoreductase from Acetobacter pasteurianus 386B (Sequence ID: HF677570.1). The DNA fragment of accr was amplified with primer 1 (5'-TCCCCCGGGAATGGCACGTGTAGCAGGCAAGGTT-3') and primer 2 (5'-CCGGAATTCCTTATTGCGCGGTGTACCCACCATCAAT-3') and double-digested with AvaI and EcoRI, then the accr fragment was inserted into vector pGEX$2 \mathrm{~T}$, the resulting plasmid (pGEX-accr) was transformed into E. coli $\mathrm{DH} 5 \alpha$ for amplification, and then the correct pGEX-accr was transformed into $E$. coli BL21(DE3) pLysS to express the recombinant AcCR. The recombinant $E$. coli BL21(DE3)pLysS(AcCR) were cultivated at $37{ }^{\circ} \mathrm{C}, 180 \mathrm{rpm}$ in $50 \mathrm{~mL} \mathrm{LB}$ medium (pH 6.5) containing $100 \mu \mathrm{g} / \mathrm{mL}$ of ampicillin. When the optical density at $600 \mathrm{~nm}\left(\mathrm{OD}_{600}\right)$ of the culture reached 1.2, the temperature was changed to $20^{\circ} \mathrm{C}$, and then IPTG was added to a final concentration of $0.4 \mathrm{mM}$. The cultivation continued at $20{ }^{\circ} \mathrm{C}$ for additional $15 \mathrm{~h}$. Then the recombinant cells were harvested by centrifugation $(8000 \mathrm{rpm}, 5 \mathrm{~min})$ at $4{ }^{\circ} \mathrm{C}$ and washed three times with physiological saline $(0.85 \%)$, and stored at $4{ }^{\circ} \mathrm{C}$ for later use.

\section{Measurement of enzymatic activity}

The oxidordeuctase activity of the recombinant AcCR was determined by monitoring the change of the absorbance at $340 \mathrm{~nm}$ for $3 \mathrm{~min}$ on the spectrophotometer (Shinmadzu UV-3010, Japan). The AcCR-catalyzed reduction of 4'-chloroacetophenone was conducted with $\mathrm{NADH}$ or NADPH at $35{ }^{\circ} \mathrm{C}$ in $2 \mathrm{~mL}$ phosphate buffer $(\mathrm{pH} 6.5$ or 5.5). One unit (U) of recombinant AcCR was defined as the amount of enzyme that catalyzed the $1 \mu \mathrm{mol} \mathrm{NADH}$ or NADPH per minute. The NAD ${ }^{+}$and $\mathrm{NADP}^{+}$-linked oxidations catalyzed by $\mathrm{AcCR}$ were conducted with isopropanol as substrate and $\mathrm{NAD}^{+}$ or $\mathrm{NADP}^{+}$at $45{ }^{\circ} \mathrm{C}$ in $2 \mathrm{~mL} 50 \mathrm{mM}$ citrate-phosphate buffer ( $\mathrm{pH}$ 8.0). One unit (U) of AcCR was defined as the amount of enzyme that catalyzed the production of $1 \mu \mathrm{mol}$ NADH or NADPH per minute. The reaction solution was incubated at 35 or $45^{\circ} \mathrm{C}$ for $3 \mathrm{~min}$, and then $20 \mu \mathrm{L}$ recombinant AcCR (about $0.008 \mathrm{mg}$ of the purified enzyme) was added to proceed the reaction.

\section{Purification of recombinant AcCR}

The harvested recombinant E. coli BL21(DE3) pLysS(AcCR) cells were suspended in $50 \mathrm{mM}$ citratephosphate buffer ( $\mathrm{pH} 6.5$ ) at the concentration of $50 \mathrm{mg} /$ $\mathrm{mL}$, ultrasonicated for $3 \times 18 \mathrm{~min}$, and then the cells debris was removed by centrifugation at $12,000 \mathrm{rpm}$ at $4{ }^{\circ} \mathrm{C}$ for $20 \mathrm{~min}$. The resulting supernatant was filtered with $0.22-\mu \mathrm{m}$ filter membrane before the purification process. The general step of the purification using NGC Quest ${ }^{\mathrm{TM}} 10$ system was as follows. First, the GST-based affinity chromatography column $(5 \mathrm{~mL})$ 
was pre-equilibrated using buffer A (4.3 $\mathrm{mM} \mathrm{Na}_{2} \mathrm{HPO}_{4}$, $1.47 \mathrm{mM} \mathrm{KH}_{2} \mathrm{PO}_{4}, 137 \mathrm{mM} \mathrm{NaCl}, 2.7 \mathrm{mM} \mathrm{KCl}, \mathrm{pH} 7.3$ ), and then the crude enzyme was loaded on the column. After that, the loaded column was first subjected to washing with 10 column volume buffer A to remove the unbound protein fractions, then washed sequentially with buffer $\mathrm{B}$ (added $0.5 \mathrm{M} \mathrm{NaCl}$ in buffer A) to remove some stubborn protein, and then buffer A was used once again to lower the salinity. At last, the target protein was eluted with buffer $\mathrm{C}(50 \mathrm{mM}$ Tris- $\mathrm{HCl}, 2.5 \mathrm{~g} / \mathrm{L}$ glutathione, $\mathrm{pH}$ 8.0). The protein content was measured by the method of Bradford (1976).

\section{Enzymatic characteristic of the recombinant AcCR Effect of temperature}

The effects of temperature on the activity of recombinant AcCR were determined at various temperatures from 20 to $55^{\circ} \mathrm{C}$. For thermal stability determination, the enzyme was pre-incubated at various temperatures ranging from 20 to $55{ }^{\circ} \mathrm{C}$, equivalent was taken at a certain time, and the residual activity was determined as described in "Measurement of enzymatic activity." The coenzyme $\mathrm{NADH}$ and $\mathrm{NAD}^{+}$was used for the reduction of $4^{\prime}$-chloroacetophenone $(5 \mathrm{mM})$ and the oxidation of the isopropanol $(150 \mathrm{mM})$, respectively. The enzyme activity of the first measurement was defined as $100 \%$.

\section{Effect of $p H$}

The optimum $\mathrm{pH}$ of recombinant $\mathrm{AcCR}$ was investigated within a $\mathrm{pH}$ range of 4.5-9.5 using various buffer systems at $50 \mathrm{mM}$. The buffers were as follows: citratephosphate ( $\mathrm{pH} 4.5-8.0)$, Tris- $\mathrm{HCl}(\mathrm{pH} 8.0-8.5)$ and glycine- $\mathrm{NaOH}(\mathrm{pH} 8.6-9.5)$. The $\mathrm{pH}$ stability was evaluated by pre-incubating the recombinant AcCR in different $\mathrm{pH}$ buffers (4.5-9.5) at $4{ }^{\circ} \mathrm{C}$ for 4 days. Samples were taken at a certain time, and the residual activity was determined as described above with the non-incubated recombinant AcCR as the control.

\section{Effect of metal ions and chemical agents}

The influence of metal ions and chemical agents on the catalytic activity of recombinant AcCR was investigated by pre-incubating the enzyme with various additives in citrate-phosphate buffer ( $50 \mathrm{mM}, \mathrm{pH} 6.5$ ) at $35{ }^{\circ} \mathrm{C}$ for $30 \mathrm{~min}$. The enzyme activity was determined under the condition described above using $\mathrm{NADH}$ as coenzyme. The enzyme activity of the recombinant AcCR in the absence of additives was recorded as $100 \%$.

\section{Substrate specificity and bioconversion of various carbonyl compounds}

The activity of recombinant AcCR for each specific substrate was measured by the method described above using $\mathrm{NADH}$ as the coenzyme. The relative activity of recombinant AcCR to $4^{\prime}$-chloroacetophenone was defined as $100 \%$.

The reduction of various carbonyl compounds were performed in a $10-\mathrm{mL}$ conical flask with $4 \mathrm{~mL}$ citratephosphate buffer $(50 \mathrm{mM}, \mathrm{pH} 6.5)$ containing $50 \mathrm{mM}$ each substrate, $0.1 \mathrm{mM} \mathrm{NADH}$, and $150 \mathrm{mM}$ isopropanol. The reactant was pre-incubated in a shaker at $35{ }^{\circ} \mathrm{C}$ for $10 \mathrm{~min}$, and then $8 \mathrm{U}$ recombinant $\mathrm{AcCR}$ was added to initiate the reaction. Samples $(25 \mu \mathrm{L})$ were withdrawn after reaction for a certain time, and then the product and residual substrate were extracted with ethyl acetate $(2 \times 25 \mu \mathrm{L}, 5 \mathrm{mM} n$-dodecane as internal standard) before $\mathrm{GC}$ analysis.

\section{Kinetic parameters assays}

For the kinetic analysis, the initial reaction rates of the recombinant AcCR were determined under the optimum conditions. For the reduction of $4^{\prime}$-chloroacetophenone, the coenzyme NADH or NADPH varied from 0.05 to $0.6 \mathrm{mM}$ or from 0.05 to $1.0 \mathrm{mM}$, and the concentrations of $4^{\prime}$-chloroacetophenone were from 0.5 to $10 \mathrm{mM}$. For the oxidation of isopropanol, the concentrations of $\mathrm{NAD}^{+}$or $\mathrm{NADP}^{+}$varied from 0.05 to $2 \mathrm{mM}$ or from 0.5 to $20 \mathrm{mM}$. The isopropanol concentrations were from 30 to $275 \mathrm{mM}$. All the measurements were carried out in duplicate. Michaelis-Menten was used to fit the data, and the kinetic parameters of recombinant AcCRcatalyzed reduction and oxidation reactions, $K_{\mathrm{m}}$ and $V_{\max }$ values, were obtained in the fit before computing the $K_{\text {cat }}$.

\section{GC methods}

The organic extracts of reaction mixtures were analyzed by a GC analysis (Shimadzu Corp GC 2010). GC was performed using chiral columns HP Chiral 10B and CPChiralsil-Dex-CB. The initial reaction rate, the yield, and the product e.e. of those reactions were calculated as described in our previous report (Wang et al. 2013).

\section{Results and discussion}

Sequence analysis of AcCR

A 762-bp polynucleotide sequence was amplified by PCR from the genome DNA of Acetobacter sp. CCTCC M209061. The sequence was an intact open reading frame and encoded a predicted protein of 253 amino acid residues with a molecular weight of about $26.4 \mathrm{kDa}$. The GenBank accession number of the nucleotide sequence of AcCR gene is MF419650. The result of multiple sequence alignment with NCBI protein blast is shown in Fig. 1. The AcCR amino acid sequence displayed a high level of similarity to the identical proteins from other Acetobacter and related bacteria. The identities of AcCR with other proteins were as follows: $84 \%$ with 3-beta 

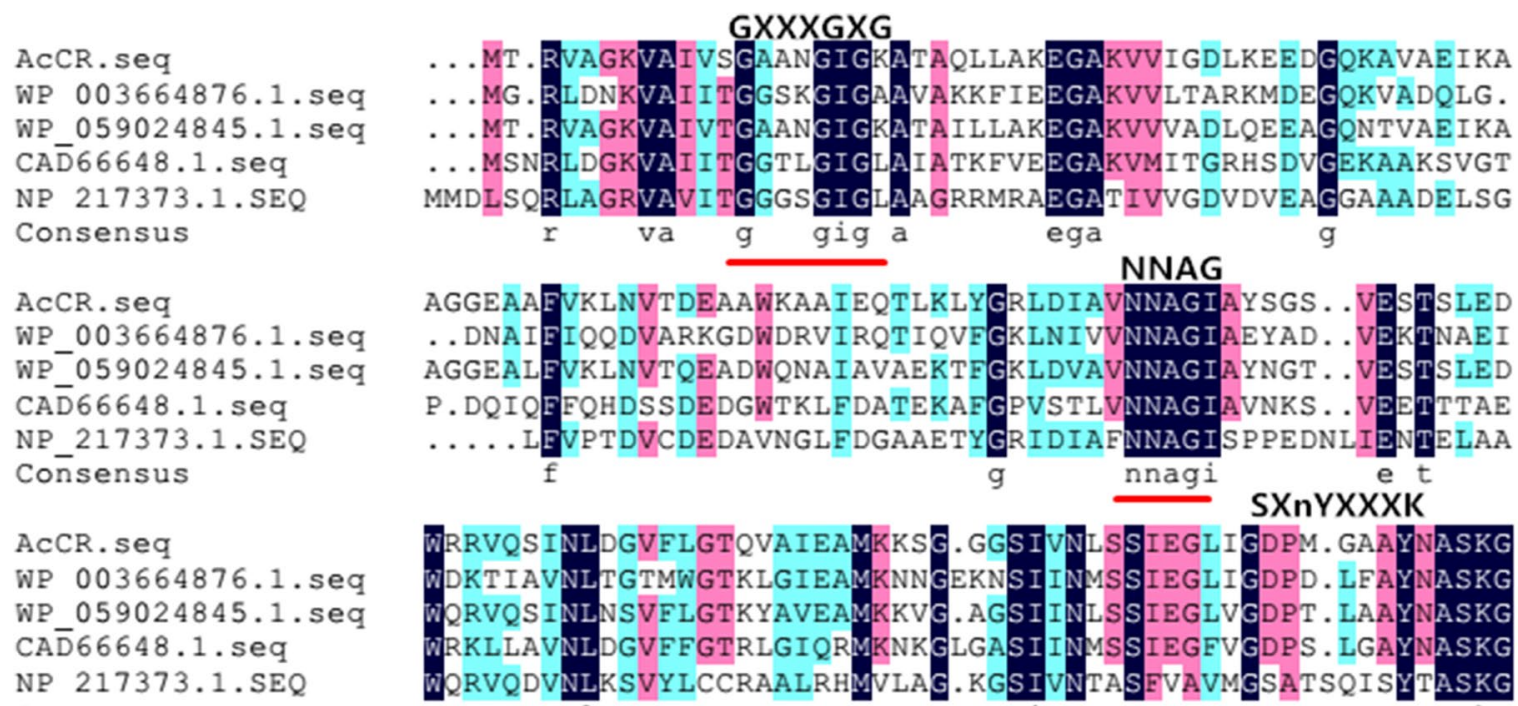

\section{NNAG}

AGGEAAFVKLNVT DEAAWKKAAIEQTLKLYGRLDIAVNNAGIAYSGS . VESTSLED .. DNAIFIQQDVARKGDWDRVIRQTIQVFGKLNIVVNNAGIAEYAD . .VEKTNAEI AGGEALEVKLNVTQEADWQNAIAVAEKTFGKLDVAVNNAGIAYNGT . .VESTSLED P.DQIQEFQHDSSDEDGWTKLFDATEKAFGPVSTLVNNAGIAVNKS . VEETTTAE .... LEVPTDVCDEDAVNGLFDGAAETYGRIDIAFNNAGISPPEDNLI ENTELAA

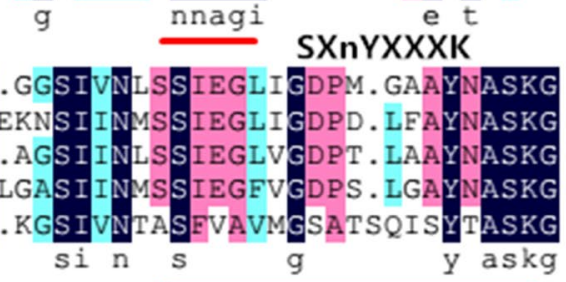

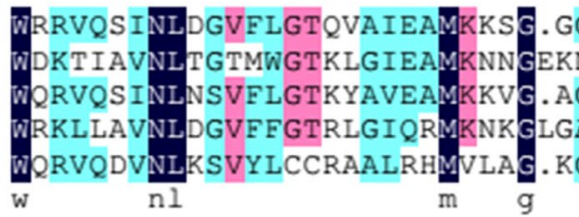
$1 \mathrm{n}$

g $\mathrm{y}$ askg
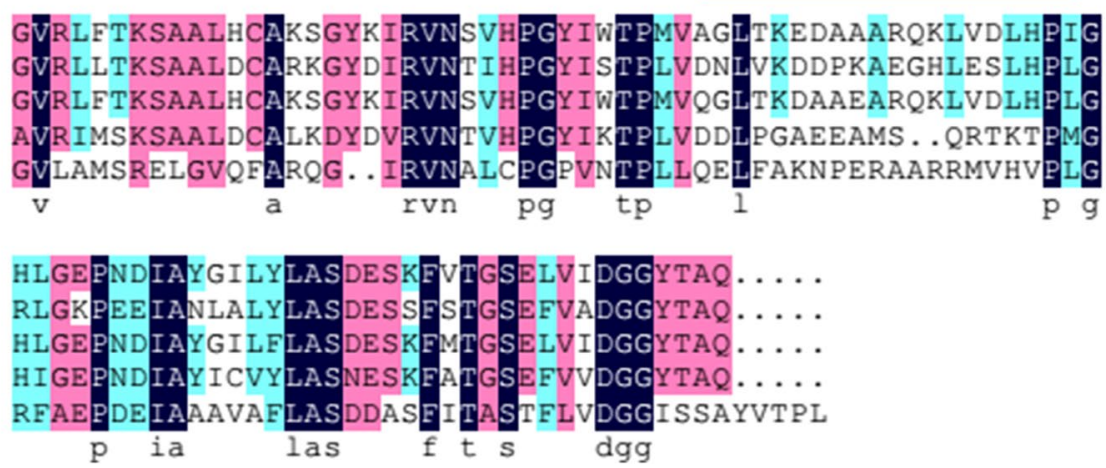

Fig. 1 Alignment of multiple deduced amino acid sequences of AcCR and carbonyl reductases from other sources hydroxysteroid dehydrogenase from Acetobacter ghanensis (WP_059024845.1), 56\% with Cyclopentanol dehydrogenase from Mesorhizobium plurifarium (CDX57396.1), $51 \%$ with $R$-specific alcohol dehydrogenase from Lactobacillus brevis (CAD66648.1), and 37\% with short-chain type dehydrogenase/reductase from Mycobacterium tuberculosis H37Rv (NP_217373.1), respectively. The amino acid sequence alignments of the deduced polypeptides of AcCR with the short-chain dehydrogenase/ reductase (SDR) proteins from GenBank database were performed. The conserved sequence (GXXXGXG) (Rossman fold motif) (Masud et al. 2011; Jörnvall et al. 2010) reported importantly of the coenzyme binding site of SDR family enzyme was found at the $\mathrm{N}$-terminal 13-19 position of the AcCR. And the common active site conserved amino acid pattern SXnYXXXK was emerged at the mid-chain pattern $142-159$, as well as the NNAG (89-92) sequence which has a function in stabilizing $\beta$-strands of classical SDR (Persson et al. 2003; Filling et al. 2002). Therefore, the AcCR could be classified as the SDR which belongs to a bulky dehydrogenase/reductase family.

\section{Expression and purification of recombinant AcCR}

The accr was constructed into plasmid pGEX-2T and transformed into E. coli. BL21(DE3)pLysS. SDS-PAGE analysis of the crude extracts indicated that the recombinant AcCR was successfully expressed in the soluble form with the GST tag (shown in Fig. 2). As a GST-tagged fusion protein, the GAcCR (recombinant AcCR) was purified by a single-step affinity chromatography using a GST-tagged column. As expected, the purified GAcCR was observed at the position of approximately $53 \mathrm{kDa}$ (the GST tag is about $26 \mathrm{kDa}$ ) which was consistent with the estimated value (Fig. 2). The purified recombinant AcCR activity was $5.17 \mathrm{U} / \mathrm{mg}$ and stored at $4{ }^{\circ} \mathrm{C}$ for later use. 


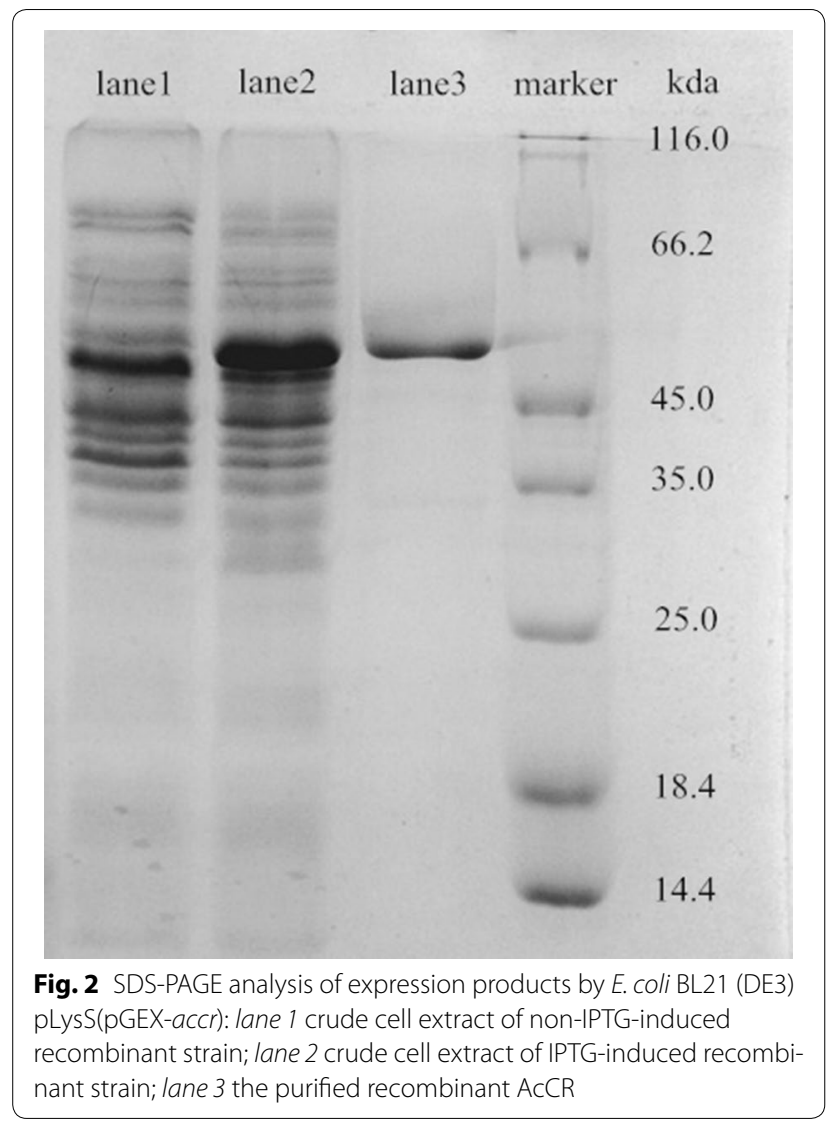

\section{Enzymatic characteristic of the recombinant AcCR Coenzyme preference of recombinant AcCR}

SDRs act on the substrate by transferring electrons from or to coenzyme. The recombinant AcCR was found to be a kind of carbonyl reductase which could use both $\mathrm{NAD}(\mathrm{H})$ and $\mathrm{NADP}(\mathrm{H})$ as coenzyme to execute the redox reactions. The coenzyme preference of the recombinant AcCR was examined by measuring enzyme activity using 4 '-chloroacetophenone or isopropanol as substrate. As shown in Fig. 3, the recombinant AcCR showed redox activity with both $\mathrm{NAD}(\mathrm{H})$ and $\mathrm{NADP}(\mathrm{H})$ as coenzymes. Meanwhile, the relative activity of the recombinant AcCR with NADPH as coenzyme was only about $40 \%$ of that with NADH, which confirmed that AcCR exhibited coenzyme specificity for NADH over NADPH. In the recent reports, many biocatalysts catalyzing asymmetric reductions utilize NADPH as hydrogen donor (Leuchs and Greiner 2011; Richter and Hummel 2011; Ma et al. 2013; Zhang et al. 2015). ADHs capable of utilizing NADH as the coenzyme outperformed NADPH-dependent ones, since NADH was more stable than NADPH under operational conditions ( $\mathrm{Li}$ et al. 2015) and economic than NADPH. The NAD $(\mathrm{H})$-preferred CRs could be

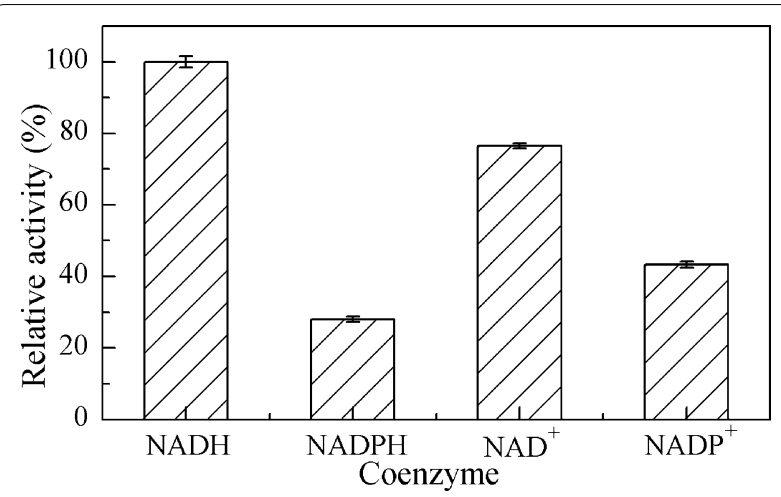

Fig. 3 Coenzyme preference of the recombinant AcCR. Reaction conditions: $0.25 \mathrm{mM} \mathrm{NADH}$ or NADPH (0.5 mM NAD ${ }^{+}$or $\mathrm{NADP}^{+}$), $2 \mathrm{~mL} 50 \mathrm{mM}$ citrate-phosphate buffer ( $\mathrm{pH} 6.5$ for the reduction or pH 8.0 for oxidation), and $5 \mathrm{mM} 4^{\prime}$-chloroacetophenone $(150 \mathrm{mM}$ isopropanol) were incubated for $5 \mathrm{~min}$ at $35^{\circ} \mathrm{C}$ before adding $20 \mu \mathrm{L}$ purified recombinant AcCR (about $0.008 \mathrm{mg}$ of the purified enzyme), and then the changes of absorbance for 3 min were recorded

advantageous for their application in industrial bioreduction system. Therefore, $\mathrm{NAD}(\mathrm{H})$ was used as the coenzyme of the enzymatic characteristic of the recombinant AcCR in the subsequent study.

\section{Effect of temperature}

Initially, the effect of varying temperatures on the activity of recombinant AcCR was explored on both reduction and oxidation reactions. The optimal temperature was found to be $35{ }^{\circ} \mathrm{C}$ for the reduction of $4^{\prime}$-chloroacetophenone when NADH was used as the coenzyme (Fig. 4a). For the case of the oxidation of isopropanol, the maximum activity was observed at $45^{\circ} \mathrm{C}$ with $\mathrm{NAD}^{+}$as coenzyme (Fig. 4a). The thermal stability of the recombinant AcCR was investigated at various temperatures ranging from 20 to $55^{\circ} \mathrm{C}$. As illustrated in Fig. $4 \mathrm{~b}$, the enzyme activity decreased slowly when the incubation temperature was less than $35^{\circ} \mathrm{C}$. The relative activity was over $50 \%$ after $36 \mathrm{~h}$ incubation at $30{ }^{\circ} \mathrm{C}$, and even more than $62 \%$ after incubating for $24 \mathrm{~h}$ at $35{ }^{\circ} \mathrm{C}$ and over $5 \mathrm{~h}$ at $50{ }^{\circ} \mathrm{C}$. Thus, the thermal stability of recombinant AcCR was excellent and much better than many reported carbonyl reductases from other sources (Xu et al. 2015; Singh et al. 2009; Luo et al. 2015; Wang et al. 2015). The enzyme exhibited half-lives of $25.75 \mathrm{~h}$ at $35^{\circ} \mathrm{C}$ and $13.93 \mathrm{~h}$ at $45{ }^{\circ} \mathrm{C}$, respectively, for the reduction and oxidation reactions.

\section{Effect of $p H$}

The effect of $\mathrm{pH}$ on recombinant AcCR was detected in different buffer systems $(50 \mathrm{mM})$ at the range from 4.5 to 9.5 for both reduction and oxidation. The maximum 

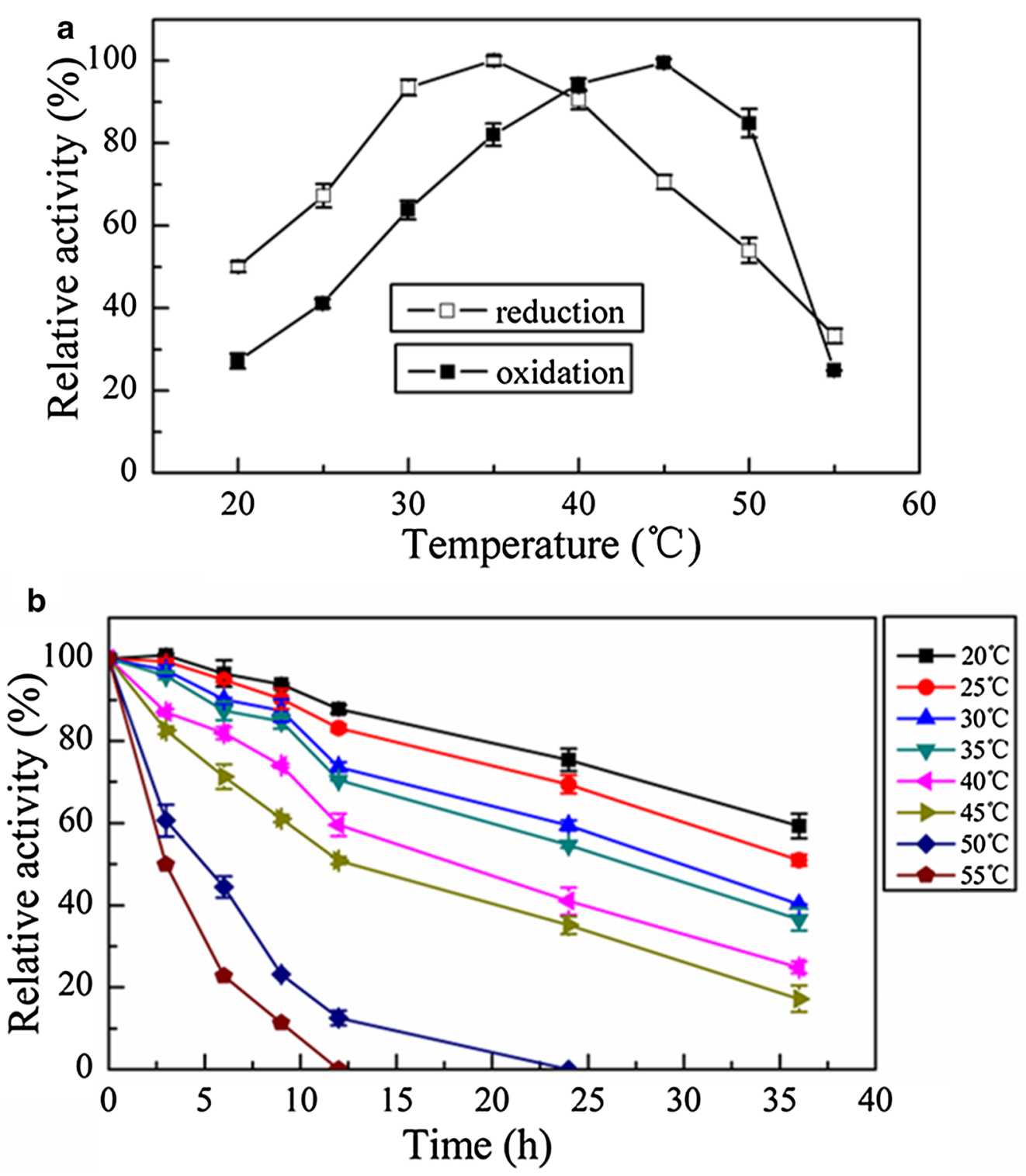

Fig. 4 Effects of temperature on the activity and stability of the recombinant AcCR. Reaction conditions: a $0.25 \mathrm{mM} \mathrm{NADH}$ or $0.5 \mathrm{mM} \mathrm{NAD}$, $2 \mathrm{~mL}$ $50 \mathrm{mM}$ citrate-phosphate buffer ( $\mathrm{pH} 6.5$ or 8.0), and $5 \mathrm{mM} 4^{\prime}$-chloroacetophenone or $150 \mathrm{mM}$ isopropanol were incubated at 20-55 ${ }^{\circ} \mathrm{C}$ for $5 \mathrm{~min}$ before adding $20 \mu \mathrm{L}$ purified recombinant $\mathrm{AcCR}$ (about $0.008 \mathrm{mg}$ of the purified enzyme), and the changes of absorbance for $3 \mathrm{~min}$ at $20-55^{\circ} \mathrm{C}$, respectively, were recorded; b $0.25 \mathrm{mM} \mathrm{NADH}, 2 \mathrm{~mL} 50 \mathrm{mM}$ citrate-phosphate buffer ( $\mathrm{pH}$ 6.5), and $5 \mathrm{mM} 4^{\prime}$-chloroacetophenone were incubated for $5 \mathrm{~min}$ at $35^{\circ} \mathrm{C}$, then added $20 \mathrm{\mu L}$ purified recombinant AcCR (about $0.008 \mathrm{mg}$ of the purified enzyme, incubated at $20-55^{\circ} \mathrm{C}$ ), and the changes of absorbance for 3 min were recorded

activity of the recombinant AcCR for reduction of 4 -chloroacetophenone was obtained at $\mathrm{pH}$ 6.5. As shown in Fig. $5 \mathrm{a}$, the relative activity was over $90 \%$ in the reduction reaction at the pHs between 6.0 and 8.0. The optimal $\mathrm{pH}$ for oxidation of isopropanol was found to be $\mathrm{pH} 8.5$ when $\mathrm{NAD}^{+}$was acted as coenzyme (Fig. 5b). The optimal $\mathrm{pH}$ of the recombinant AcCR for catalyzing reduction and oxidation is close to that of the oxidoreductase from Gluconobacter oxydans (Liu et al. 2014).
To investigate the $\mathrm{pH}$ stability, the recombinant $\mathrm{AcCR}$ was incubated at $4{ }^{\circ} \mathrm{C}$ in varying pHs from 4.5 to 9.5 and tested the reduction activity using NADH as coenzyme. As shown in Fig. 5c, the optimal storage $\mathrm{pH}$ was 6.5, at which $\mathrm{pH}$ almost $80 \%$ relative activity remained after $96 \mathrm{~h}$. Almost $70 \%$ relative activities remained at both $\mathrm{pH}$ 7.0 and 7.5 after $96 \mathrm{~h}$, as well as at $\mathrm{pH} 6.0$ after $75 \mathrm{~h}$. The results showed that the recombinant AcCR had broad $\mathrm{pH}$ tolerant scope and excellent $\mathrm{pH}$ stability. 

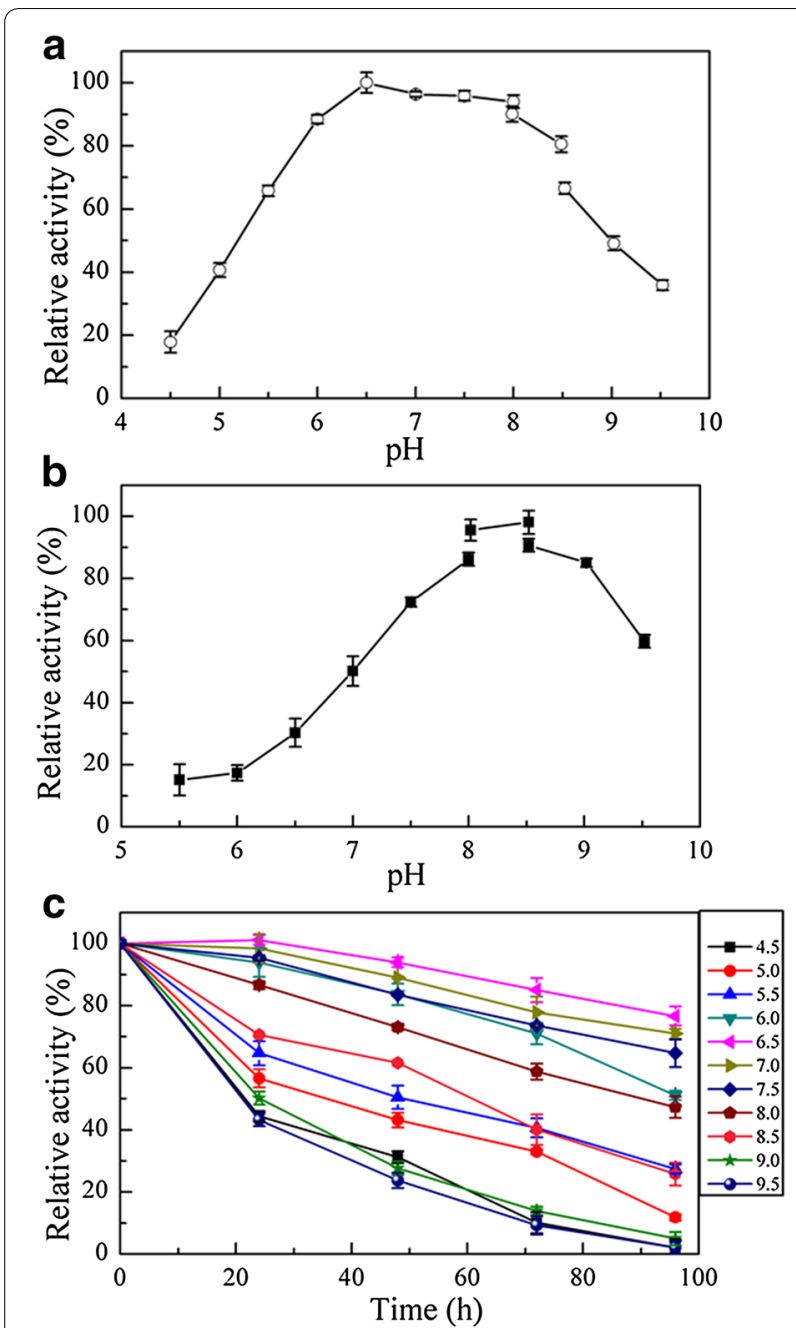

Fig. 5 Effects of $\mathrm{pH}$ on the activity and stability of the recombinant AcCR. Reaction conditions: a 0.25 mM NADH, 2 mL 50 mM buffer ( $\mathrm{pH} 4.5-9.5$ ), and $5 \mathrm{mM} \mathrm{4}$ '-chloroacetophenone were incubated at $35^{\circ} \mathrm{C}$ for $5 \mathrm{~min}$ before adding $20 \mu \mathrm{L}$ purified recombinant $\mathrm{AcCR}$ (about $0.008 \mathrm{mg}$ of the purified enzyme), and then the changes of absorbance for $3 \mathrm{~min}$ at $35^{\circ} \mathrm{C}$ were recorded; $\mathbf{b} 0.5 \mathrm{mM} \mathrm{NAD}+2 \mathrm{~mL}$ $50 \mathrm{mM}$ buffer (pH 5.5-9.5), and $150 \mathrm{mM}$ isopropanol were incubated at $45^{\circ} \mathrm{C}$ for 5 min before adding $20 \mu \mathrm{L}$ purified recombinant $\mathrm{AcCR}$ (about $0.008 \mathrm{mg}$ of the purified enzyme), and then the changes of absorbance for $3 \mathrm{~min}$ at $45^{\circ} \mathrm{C}$ were recorded; c $0.25 \mathrm{mM} \mathrm{NADH}$, $2 \mathrm{~mL} 50 \mathrm{mM}$ buffer ( $\mathrm{pH} 4.5-9.5$ ), and $5 \mathrm{mM} 4^{\prime}$-chloroacetophenone were incubated for $5 \mathrm{~min}$ at $35^{\circ} \mathrm{C}$, then $20 \mu \mathrm{L}$ purified recombinant AcCR was added (about $0.008 \mathrm{mg}$ of the purified enzyme), and the changes of absorbance for 3 min were recorded

\section{Effect of metal ions and chemical agents}

It is well known that metal ions have remarkable effects on the activity of carbonyl reductase. For example, $\mathrm{Zn}^{2+}$ is necessary for many medium-chain dehydrogenases/reductases ( $\mathrm{Zn}$-MDR). The $\mathrm{Zn}^{2+}$ appears in those enzymes to give the protein an additional strength, as if compensating for domain variability and evolutionary changes in the protein scaffold (Jörnvall et al. 2010). Besides, some metal ions also have negative effect on the activity of a number of enzymes. For example, $\mathrm{Co}^{2+}$, $\mathrm{Cu}^{2+}$, and $\mathrm{Zn}^{2+}$ can severely inhibit the enzyme activity of carbonyl reductase SCRII from Candida parapsilosis (Zhang et al. 2011). So it is of significantly important to explore the effects of various additives on the recombinant AcCR. As shown in Table 1, among the tested metal ions, $\mathrm{Mn}^{2+}, \mathrm{K}^{+}, \mathrm{Fe}^{2+}, \mathrm{Mg}^{2+}, \mathrm{Ca}^{2+}$, and $\mathrm{Co}^{2+}$ had slight stimulation on the recombinant $\mathrm{AcCR}$, while the other metal ions had inhibitory effects to some extent. Enzyme activity was inhibited about 5 and $15 \%$ when 2 and $5 \mathrm{mM}$ $\mathrm{Zn}^{2+}$ was added, and the residue enzyme activity was only 43.0 and $24.9 \%$ when 2 and $5 \mathrm{mM} \mathrm{Cu}^{2+}$ was added, respectively. $\mathrm{Ag}^{+}$and $\mathrm{Hg}^{+}$inhibited the enzyme activity completely.

The effect of chemical agents including metal-chelator, surfactants, and sulfhydryl reagents on the recombinant AcCR was presented in Table 2. EDTA had almost no effect on the enzyme activity of the recombinant

Table 1 Effects of metal ions on the enzymatic activity of the recombinant ACCR

\begin{tabular}{|c|c|c|}
\hline Reagent & Concentration (mM) & Relative activity (\%) \\
\hline Control & & $100.0 \pm 0.8$ \\
\hline \multirow[t]{2}{*}{$\mathrm{Mn}^{2+}$} & 2 & $122.3 \pm 0.4$ \\
\hline & 5 & $119.9 \pm 0.7$ \\
\hline \multirow[t]{2}{*}{$\mathrm{K}^{+}$} & 2 & $110.6 \pm 1.2$ \\
\hline & 5 & $103.4 \pm 0.8$ \\
\hline \multirow[t]{2}{*}{$\mathrm{Fe}^{2+}$} & 2 & $106.7 \pm 1.0$ \\
\hline & 5 & $106.0 \pm 2.9$ \\
\hline \multirow[t]{2}{*}{$\mathrm{Zn}^{2+}$} & 2 & $94.8 \pm 1.2$ \\
\hline & 5 & $85.8 \pm 1.3$ \\
\hline \multirow[t]{2}{*}{$\mathrm{Mg}^{2+}$} & 2 & $115.7 \pm 0.7$ \\
\hline & 5 & $123.5 \pm 2.4$ \\
\hline \multirow[t]{2}{*}{$\mathrm{Ba}^{2+}$} & 2 & $100.8 \pm 0.5$ \\
\hline & 5 & $97.9 \pm 1.7$ \\
\hline \multirow[t]{2}{*}{$\mathrm{Ca}^{2+}$} & 2 & $116.7 \pm 0.6$ \\
\hline & 5 & $113.9 \pm 1.0$ \\
\hline \multirow[t]{2}{*}{$\mathrm{Cu}^{2+}$} & 2 & $43.0 \pm 0.7$ \\
\hline & 5 & $24.9 \pm 0.7$ \\
\hline \multirow[t]{2}{*}{$\mathrm{Co}^{2+}$} & 2 & $99.6 \pm 2.1$ \\
\hline & 5 & $113.8 \pm 0.2$ \\
\hline \multirow[t]{2}{*}{$\mathrm{Hg}^{2+}$} & 2 & $\mathrm{Nd}$ \\
\hline & 5 & $\mathrm{Nd}$ \\
\hline \multirow[t]{2}{*}{$\mathrm{Ag}^{+}$} & 2 & $\mathrm{Nd}$ \\
\hline & 5 & $\mathrm{Nd}$ \\
\hline
\end{tabular}

Reaction conditions: $0.5 \mathrm{mM} \mathrm{NADH}, 2 \mathrm{~mL} 50 \mathrm{mM}$ citrate-phosphate buffer (pH 6.5) with different metal ions, and $5 \mathrm{mM} \mathrm{4} 4^{\prime}$-chloroacetophenone were incubated for $10 \mathrm{~min}$ at $35^{\circ} \mathrm{C}$ before adding $20 \mu \mathrm{L}$ purified recombinant AcCR (about $0.008 \mathrm{mg}$ of the purified enzyme), and recorded the changes of absorbance for $3 \mathrm{~min}$ 
Table 2 Effects of chemical agents on the recombinant ACCR

\begin{tabular}{|c|c|c|}
\hline Reagent & Concentration (mM) & Relative activity (\%) \\
\hline Control & & $100.0 \pm 0.8$ \\
\hline \multirow[t]{2}{*}{ EDTA } & 2 & $95.7 \pm 2.3$ \\
\hline & 5 & $92.4 \pm 2.9$ \\
\hline \multirow[t]{2}{*}{ SDS } & 2 & $68.4 \pm 1.2$ \\
\hline & 5 & $53.4 \pm 1.4$ \\
\hline \multirow[t]{2}{*}{$\beta$-Mercaptoethanol } & 20 & $94.2 \pm 2.0$ \\
\hline & 40 & $88.1 \pm 2.0$ \\
\hline \multirow[t]{2}{*}{ lodoacetamide } & 20 & $97.1 \pm 1.4$ \\
\hline & 40 & $85.3 \pm 1.2$ \\
\hline \multirow[t]{2}{*}{ Tween-80 } & $1 \%(v / v)$ & $74.1 \pm 1.9$ \\
\hline & $2 \%(v / v)$ & $66.9 \pm 1.8$ \\
\hline \multirow[t]{2}{*}{ Triton X-100 } & $1 \%(v / v)$ & $86.8 \pm 1.9$ \\
\hline & $2 \%(v / v)$ & $71.0 \pm 2.0$ \\
\hline
\end{tabular}

Reaction conditions: $0.25 \mathrm{mM} \mathrm{NADH}, 2 \mathrm{~mL} 50 \mathrm{mM}$ citrate-phosphate buffer ( $\mathrm{pH}$ 6.5) with different chemical agents, $5 \mathrm{mM} 4$ '-chloroacetophenone were incubated for $10 \mathrm{~min}$ at $35^{\circ} \mathrm{C}$ before adding $20 \mu \mathrm{L}$ purified recombinant AcCR (about $0.008 \mathrm{mg}$ of the purified enzyme), and the changes of absorbance for $3 \mathrm{~min}$ were recorded

AcCR, revealing that the recombinant AcCR was a metalion-independent enzyme. The metal-ion-independent enzyme was conformed to the characteristic of the vast majority of SDRs (Kavanagh et al. 2008; Persson and Kallberg 2013). The sulfhydryl reagents, $\beta$-mercaptoethanol and iodoacetamide, had no significant effect on the recombinant AcCR activity, suggesting that there were no essential disulfide linkages and - $\mathrm{SH}$ groups at the catalytic sites of the recombinant AcCR (Dako et al. 2008). Surfactants were reported to play a key role in the catalytic activity of several enzymes (Ye et al. 2009). The surfactants such as SDS, Tween-80, and Triton X-100 had obviously inhibitory effect on the activity of the recombinant AcCR, which could be due to fact that the surfactants partially disrupted the hydrophobic interactions and increased the internal repulsive forces (Adler et al. 2000).

\section{Substrate specificity and bioconversion of various carbonyl compounds}

Most carbonyl reductases can catalyze reversible reaction mediated by different coenzymes, and the substrate specificity and stereoselectivity are different towards certain carbonyl reductase (He et al. 2014; Zhang et al. 2015; Takeuchi et al. 2015; Tang et al. 2014). Therefore, it was of great interest to investigate the capability of the recombinant AcCR for catalyzing redox reaction, substrate specificity, and stereoselectivity. Seventeen of prochiral carbonyl compounds and their corresponding alcohols were explored using $\mathrm{NADH}$ or $\mathrm{NAD}^{+}$as coenzyme (Scheme 1), and the results are shown in Table 3. Glancing

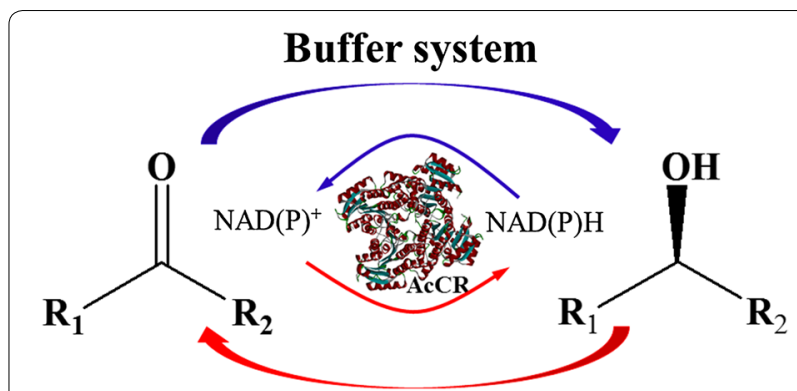

Scheme 1 The general procedure of AcCR to conduct the oxidoreduction reaction with $\mathrm{NAD}(\mathrm{P})(\mathrm{H})$

at the results, we found that the AcCR could not only catalyze the reduction of carbonyl groups but also could complete the dehydrogenization of the partial tested alcohols. The activities of ketones reduction were higher than those of oxidation of alcohols obviously, which was beneficial to proceed ketones reduction. The oxidation of ethyl $(R)$ (+)-4-chloro-3-hydroxybutyrate or ethyl (S)-(-)-4-chloro3-hydroxybutyrate was investigated, respectively, and no oxidative activity was tested. But when ethyl-4-chloroacetoacetate was used as substrate, the relative activity was tested to be $120.6 \%$, indicating that the reaction was not reversible towards ethyl-4-chloroacetoacetate and ethyl (4-chloro-3-hydroxybutyrate. In addition, using 2-(R)octanol or 2-(S)-octanol as substrate, the relative activity of AcCR was far from each other (107.7\% vs $2.9 \%)$, which attested that the AcCR also had stereoselectivity on the oxidation of enantiomer alcohols substrates.

Chiral alcohols are one of the most useful building blocks for the preparation of pharmaceuticals. As the excellent relative activity of the recombinant AcCR towards those prochiral carbonyl-group substrates, it is of great interest to investigate the product yields and enantiomeric excess (e.e.) of the asymmetric reduction of the carbonyl compounds catalyzed by the recombinant AcCR. As shown in Table 4, AcCR exhibits a broad substrate spectrum and the enantioselectivity of this enzyme follows anti-Prelog rule which are relatively rare in nature (Tang et al. 2014; Li et al. 2015). The results shown in Tables 3 and 4 indicated that the relative activity was affected by the position of the substituents, such as the $2^{\prime}$-, $3^{\prime}$ - and $4^{\prime}$-positions substituted acetophenone, $2^{\prime}$-methoxyacetophenone (16.5\%), 3'-methoxyacetophenone (3.1\%), and $4^{\prime}$-methoxyacetophenone (10.7\%). High product yield and excellent enantioselectivity (>99\%) were achieved when the $4^{\prime}$-position of acetophenone was substituted by electron-withdrawing groups such as $-\mathrm{F}$, $-\mathrm{Br}$, and $-\mathrm{NO}_{3}$, whereas the electron-releasing groups like -methyl had a negative effect on the activity of the recombinant AcCR. Moreover, it is noteworthy that the 
Table 3 The relative activity of the recombinant ACCR to catalyze the oxidation of alcohols and reduction of ketones

\begin{tabular}{|c|c|c|c|c|c|}
\hline Substrate & Structure & Relative activity (\%) & Substrate & Structure & Relative activity (\%) \\
\hline Isopropanol & & 45.4 & & & \\
\hline 1-Phenethyl alcohol & & $\mathrm{Nd}$ & Acetophenone & & 9.2 \\
\hline 1-(4-Methylphenyl)ethanol & & 16.6 & 4-Methylacetophenone & & 16.5 \\
\hline 2-Methoxyphenethyl alcohol & & 1.9 & 2-Methoxyacetophenone & & 3.1 \\
\hline 3-Methoxyphenethyl alcohol & & 7.7 & 3-Methoxyacetophenone & & 10.7 \\
\hline 4-Methoxyphenethyl alcohol & & 11.6 & 4-Methoxyacetophenone & & 5.1 \\
\hline 3,3-Dimethyl-2-butanol & он & 36.5 & 3,3-dimethyl-2-butanone & o & 47.5 \\
\hline 1-(Trimethylsilyl)-ethanol & OH & $\mathrm{Nd}$ & 1-(Trimethylsilyl)ethanone & o & 156.5 \\
\hline 4-(Trimethylsilyl)-3-butyn-2-ol & & 2.9 & $\begin{array}{l}\text { 4-(Trimethylsilyl)-3-butyn- } \\
\text { 2-one }\end{array}$ & & 114.4 \\
\hline Methyl 3-hydroxybutyrate & & 13.1 & Methyl acetoacetate & & 81.1 \\
\hline Ethyl 3-hydroxybutyrate & & 6.2 & Ethyl acetoacetate & & 52.1 \\
\hline $\begin{array}{l}\text { Ethyl } \\
\text { (R)-4-chloro-3-hydroxybu- } \\
\text { tyrate }\end{array}$ & & $\mathrm{Nd}$ & Ethyl-4-chloroacetoacetate & & 120.6 \\
\hline $\begin{array}{l}\text { Ethyl } \\
\text { (S)-4-chloro-3-hydroxybu- } \\
\text { tyrate }\end{array}$ & & $\mathrm{Nd}$ & & & \\
\hline 1-(4-Fluorophenyl)ethanol & & 55.1 & 4-Fluoroacetophenone & & 85.1 \\
\hline 1-(4-Chlorophenyl)ethanol & & 52.3 & 4-Chloroacetophenone & & 100.0 \\
\hline 1-(4-Bromophenzyl) alcohol & & 44.2 & 4-Bromoacetophenone & & 117.1 \\
\hline 1-(4-Nitrophenzyl) alcohol & & 49.6 & 4-Nitroacetophenone & & 98.7 \\
\hline 2-Pentanol & & 98.6 & 2-pentanone & & 158.6 \\
\hline
\end{tabular}


Table 3 continued

\begin{tabular}{lllll}
\hline Substrate & Structure & Relative activity (\%) & Substrate & Structure \\
\hline 2-(R)-Octanol & 2-Octanone & Relative activity (\%) \\
Ethyl 2-hydroxy-4-phenylb- \\
utyrate
\end{tabular}

Reaction conditions: for oxidation reaction (a) $0.5 \mathrm{mM} \mathrm{NAD}^{+}, 2 \mathrm{~mL} 50 \mathrm{mM}$ Tris- $\mathrm{HCl}$ buffer (pH 8.5), $50 \mathrm{mM}$ alcohol compound incubated at $45^{\circ} \mathrm{C}$ for $5 \mathrm{~min}$ before adding $20 \mu \mathrm{L}$ purified recombinant $\mathrm{AcCR}$ (about $0.008 \mathrm{mg}$ the purified enzyme), recorded the changes of absorbance for $3 \mathrm{~min}$ at $45^{\circ} \mathrm{C}$; for reduction reaction (b) $0.25 \mathrm{mM} \mathrm{NADH}, 2 \mathrm{~mL} 50 \mathrm{mM}$ citrate-phosphate buffer ( $\mathrm{pH} 6.5$ ), $50 \mathrm{mM}$ carbonyl compound at $35^{\circ} \mathrm{C}$ for 5 min before adding $20 \mu \mathrm{L}$ purified recombinant AcCR (about $0.008 \mathrm{mg}$ the purified enzyme) recorded the changes of absorbance for $3 \mathrm{~min}$ at $35^{\circ} \mathrm{C}$

Table 4 Asymmetric reduction of prochiral carbonyl compounds catalyzed by the recombinant AcCR

\begin{tabular}{|c|c|c|c|c|c|c|}
\hline Substrates & Products & Reaction time (h) & Con. ${ }^{\text {a }}$ Yield (\%) & Yield (\%) & e.e. (\%) & Config. ${ }^{b}$ \\
\hline Acetophenone & Phenethyl alcohol & 3 & 48.2 & 45 & $>99$ & $\mathrm{R}$ \\
\hline 2'-Methoxyacetophenone & 2-Methoxyphenethyl ethanol & 12 & 17.1 & 10.8 & $>99$ & $\mathrm{R}$ \\
\hline 3'-Methoxyacetophenone & 3-Methoxyphenethyl ethanol & 7 & 67.5 & 61.6 & $>99$ & $\mathrm{R}$ \\
\hline 4'-Methoxyacetophenone & 4-Methoxyphenethyl ethanol & 12 & 56.1 & 50.8 & $>99$ & $\mathrm{R}$ \\
\hline 4'-Methylacetophenone & 1-(4-Methylphenyl) ethanol & 3 & 62.8 & 57.7 & $>99$ & $\mathrm{R}$ \\
\hline 4'-Fluoroacetophenone & 1-(4-Fluorophenyl) ethanol & 7 & 99.1 & 95.6 & $>99$ & $\mathrm{R}$ \\
\hline 4'-Chloroacetophenone & 1-(4-Chlorophenyl) ethanol & 7 & 99.7 & 99.4 & $>99$ & $\mathrm{R}$ \\
\hline 4'-Bromoacetophenone & 1-(4-Bromophenyl) ethanol & 7 & 99.5 & 99.1 & $>99$ & $R$ \\
\hline 4'-Nitroacetophenone & 1-(4-Nitrophenyl) ethanol & 7 & 99.8 & 98.6 & $>99$ & $\mathrm{R}$ \\
\hline Methyl acetoacetate & Methyl 3-hydroxybutyrate & 3 & 98.7 & 94.3 & $>99$ & $\mathrm{R}$ \\
\hline Ethyl acetoacetate & Ethyl 3-hydroxybutyrate & 3 & 91.7 & 88.5 & 97.6 & $\mathrm{R}$ \\
\hline Ethyl 4'-chloroacetoacetate & Ethyl 4-chloro-3-hydroxybutanoate & 5 & 95.3 & 92.1 & $>99$ & S \\
\hline Ethyl 2-oxo-4-phenylbutyrate & Ethyl 2-hydroxy-4-phenylbutyrate & 3 & 72.9 & 68.4 & 83.1 & $\mathrm{~S}$ \\
\hline 4-(Trimethylsilyl )-3-butyn-2-one & 4-(Trimethylsilyl )-3-butyn-2-ol & 7 & 89.2 & 62.5 & $>99$ & $\mathrm{R}$ \\
\hline 3,3-dimethyl-2-butanone & 3,3-dimethyl-2-butanol & 7 & 76.5 & 61.7 & 80.7 & $\mathrm{R}$ \\
\hline 2-Octanone & 2-Octanol & 3 & 71.6 & 66.9 & $>99$ & $\mathrm{R}$ \\
\hline
\end{tabular}

a Conversion

b Configuration

Reaction conditions: $4 \mathrm{~mL}$ citrate-phosphate buffer $\left(50 \mathrm{mM}, \mathrm{pH}\right.$ 6.5) containing $50 \mathrm{mM}$ substrate, $0.1 \mathrm{mM} \mathrm{NADH}, 150 \mathrm{mM}$ isopropanol, $8 \mathrm{U}$ recombinant $\mathrm{AcCR}, 35^{\circ} \mathrm{C}$, $180 \mathrm{rpm}$

AcCR was more active to ethyl $4^{\prime}$-chloroacetoacetate among the investigated $\alpha$-ketoesters, and the relative activity and yield were over 120.6 and $92.1 \%$, respectively. The recombinant AcCR exhibited $114.4 \%$ relative activity to the 4-(trimethylsilyl)-3-butyn-2-one, and the product e.e. was over $99 \%$, but the yield was only $62.5 \%$, possibly because the substrate could be easily decomposed into a carbonyl alkyne and trimethyl hydroxysilane in buffer system with $\mathrm{pH}$ over 6.0 (Zhang et al. 2008). The product yield of reducing 3,3-dimethyl-2-butanone to 3,3-dimethyl-2-butanol was $61.7 \%$ and the product e.e was $80.7 \%$, and if further reaction continued, the product e.e decreased markedly. What is more, unlike the acetophenone reduced to corresponding $(R)$-products, ethyl 4'-chloroacetoacetate and ethyl 2-oxo-4-phenylbutyrate were catalyzed to ethyl (S)-4-chloro-3-hydroxybutyrate and $(S)$-2-hydroxy-4-phenylbutyrate, respectively, which accorded with the anti-Prelog rule that the Cahn-IngoldPrelog priority system was conversely exhibited when the substituted group contained higher priority atoms at its chiral center (Itoh 2014).

\section{Kinetic parameters assays}

The kinetic constants of the purified AcCR were calculated by fitting data by linear regression to a LineweaverBurk double reciprocal plot. All the kinetic constants for 4'-chloroacetophenone, isopropanol, $\mathrm{NAD}(\mathrm{P}) \mathrm{H}$, and $\operatorname{NAD}(\mathrm{P})^{+}$are presented in Table 5 . The results for reduction 
Table 5 Kinetic parameters of different substrates for the recombinant ACCR

\begin{tabular}{lccc}
\hline Substrate & $\boldsymbol{K}_{\mathbf{m}}(\mathbf{m M})$ & $\begin{array}{l}\boldsymbol{V}_{\mathbf{m a x}}(\boldsymbol{\mu} \mathbf{m o l} \\
\left.\mathbf{m i n}^{-1} \mathbf{m g}^{-\mathbf{1}}\right)\end{array}$ & $\boldsymbol{k}_{\mathbf{c a t}}\left(\mathbf{m i n}^{-\mathbf{1}}\right)$ \\
\hline NADH & 0.16 & 5.19 & 145.7 \\
4'-Chloroacetophenone & 0.26 & & \\
NADPH & 0.44 & 0.66 & 17.71 \\
4'-Chloroacetophenone $^{\prime}$ & 2.75 & & \\
NAD & 0.38 & 11.8 & 265.8 \\
Isopropanol & 23.8 & & \\
NADP+ & 1.39 & 1.32 & 35.94 \\
Isopropanol & 54.1 & & \\
\hline
\end{tabular}

of 4'-chloroacetophenone showed that the enzyme had a much higher affinity for NADH than NADPH. Many carbonyl reductases from microorganism preferred NADPH much more, such as ADHs from Lactobacillus (Weckbecker and Hummel 2009; Leuchs and Greiner 2011), carbonyl reductase from Gluconobacter oxydans (Chen et al. 2015), and aldo-keto reductases from Candida parapsilosis (Guo et al. 2014). The NADH as coenzyme for carbonyl reductase was heavily favored for its economy and stability (Leuchs and Greiner 2011). The results for the oxidation of isopropanol ( $\mathrm{Km}$ value 0.38 and $23.8 \mathrm{Vs} 1.39$ and 54.1 ) gave a proof that the AcCR was more affiliative to $\mathrm{NAD}^{+}$than NADP ${ }^{+}$ when conducting the oxidation. Above all, the AcCR was an $\mathrm{NAD}(\mathrm{H})$ and $\mathrm{NADP}(\mathrm{H})$ dependent oxidordeuctase and more preferred $\mathrm{NAD}(\mathrm{H})$ as coenzyme in the redox reaction.

\section{Conclusions}

The anti-Prelog carbonyl reductase AcCR from Acetobacter sp. CCTCC M209061 was cloned and its polypeptide sequence had been predicted and analyzed to confirm that the AcCR belongs to SDRs superfamily. Then AcCR was expressed heterologously, purified, and characterized. The purified enzyme preferred the inexpensive coenzyme NADH as specific electron donor. The recombinant AcCR exhibited excellent enantioselectivity, broad substrate spectrum, and highly stereoselective anti-Prelog reduction of prochiral ketones. These results suggest that AcCR is a powerful chiral tool for the production of anti-Prelog alcohols.

\section{Abbreviations}

CR: carbonyl reductase; ADH: alcohol dehydrogenase; SDR: short-chain dehydrogenase/reductase; AcCR: carbonyl reductase from Acetobacter sp. CCTCC M209061; GC: gas chromatography; IPTG: isopropyl- $\beta$-d-thiogalactoside.

\section{Authors' contributions}

Conceived and designed the experiments: WYL MHZ. Performed the experiments: PW YHC PX. Analyzed the data: WYL PW. Contributed reagents/materials/analysis tools: MHZ WYL JZ. Wrote the paper: PW WYL. All authors read and approved the final manuscript.

\section{Author details}

${ }^{1}$ Lab of Applied Biocatalysis, School of Food Science and Engineering, South

China University of Technology, Guangzhou 510640, Guangdong, China.

${ }^{2}$ School of Chemistry and Chemical Engineering, South China University

of Technology, Guangzhou 510640, Guangdong, China.

Acknowledgements

Not applicable.

Competing interests

The authors declare that they have no competing interests.

Availability of data and materials

All data generated or analyzed during this study are included in this article.

\section{Consent for publication}

All authors approved the consent for publishing the manuscript to bioresources and bioprocessing. There is no conflict of interest for any of the author regarding the submission of this manuscript.

\section{Ethics approval and consent to participate}

Not applicable.

\section{Funding}

The National Natural Science Foundation of China (21336002; 21676104; 21376096), the Fundamental Research Funds for the Chinese Universities (2015PT002; 2015ZP009), the Program of State Key Laboratory of Pulp and Paper Engineering (2017ZD05), and the Open Funding Project of the State Key Laboratory of Bioreactor Engineering.

\section{Publisher's Note}

Springer Nature remains neutral with regard to jurisdictional claims in published maps and institutional affiliations.

Received: 30 May 2017 Accepted: 17 August 2017

Published online: 28 August 2017

\section{References}

Adler JJ, Singh PK, Patist A, Rabinovich YI, Shah DO, Moudgil BM (2000) Correlation of particulate dispersion stability with the strength of self-assembled surfactant films. Langmuir 16:7255-7262

Birolli WG, Ferreira IM, Alvarenga N, Santos DDA, de Matos IL, Comasseto JV, Porto ALM (2015) Biocatalysis and biotransformation in Brazil: an overview. Biotechnol Adv 33:481-510

Bradford MM (1976) A rapid and sensitive method for the quantitation of microgram quantities of protein utilizing the principle of protein-dye binding. Anal Biochem 72:248-254

Chen R, Liu X, Wang JL, Lin JP, Wei DZ (2015) Cloning, expression, and characterization of an anti-Prelog stereospecific carbonyl reductase from Gluconobacter oxydans DSM2343. Enzyme Microb Technol 70:18-27

Cheng J, Lou W, Zong M (2014) Biocatalytic asymmetric oxidation of racemic 1-(4-methoxyphenyl) ethanol using immobilized Acetobacter sp CCTCC M209061 cells in organic solvent-containing biphasic system. Chem J Chin Univ Chin 35:1529-1535

Cui ZM, Zhang JD, Fan XJ, Zheng GW, Chang HH, Wei WL (2017) Highly efficient bioreduction of 2-hydroxyacetophenone to (S)- and (R)-1-phenyl1,2-ethanediol by two substrate tolerance carbonyl reductases with cofactor regeneration. J Biotechnol 243:1-9

Dako E, Jankowski CK, Bernier A-M, Asselin A, Simard RE (2008) A new approach for the purification and characterisation of PA49.5, the main prebiotic of Lactococcus lactis subsp. cremoris. Int J Food Microbiol 126:186-194

Filling C, Berndt KD, Benach J, Knapp S, Prozorovski T, Nordling E, Ladenstein R, Jornvall H, Oppermann U (2002) Critical residues for structure and catalysis in short-chain dehydrogenases/reductases. J Biol Chem 277:25677-25684

Grosch J-H, Loderer C, Jestel T, Ansorge-Schumacher M, Spieß AC (2015) Carbonyl reductase of Candida parapsilosis - stability analysis and stabilization strategy. J Mol Catal B Enzym 112:45-53 
Guo R, Nie Y, Mu XQ, Xu Y, Xiao R (2014) Genomic mining-based identification of novel stereospecific aldo-keto reductases toolbox from Candida parapsilosis for highly enantioselective reduction of carbonyl compounds. J Mol Catal B Enzym 105:66-73

Gutierrez MC, Ferrer ML, Yuste L, Rojo F, del Monte F (2010) Bacteria incorporation in deep-eutectic solvents through freeze-drying. Angew Chem Int Ed 49:2158-2162

He S, Wang Z, Zou Y, Chen S, Xu X (2014) Purification and characterization of a novel carbonyl reductase involved in oxidoreduction of aromatic $\beta$-amino ketones/alcohols. Process Biochem 49:1107-1112

He YC, Zhang DP, Di JH, Wu YQ, Tao ZC, Liu F, Zhang ZJ, Chong GG, Ding Y, Ma $C L$ (2016) Effective pretreatment of sugarcane bagasse with combination pretreatment and its hydrolyzates as reaction media for the biosynthesis of ethyl (S)-4-chloro-3-hydroxybutanoate by whole cells of E. coli CCZUK14. Bioresour Technol 211:720-726

Itoh N (2014) Use of the anti-Prelog stereospecific alcohol dehydrogenase from Leifsonia and Pseudomonas for producing chiral alcohols. Appl Microbiol Biotechnol 98:3889-3904

Jörnvall H, Hedlund J, Bergman T, Oppermann U, Persson B (2010) Superfamilies SDR and MDR: from early ancestry to present forms. Emergence of three lines, a Zn-metalloenzyme, and distinct variabilities. Biochem Biophys Res Commun 396:125-130

Kaluzna IA, Rozzell JD, Kambourakis S (2005) Ketoreductases: stereoselective catalysts for the facile synthesis of chiral alcohols. Tetrahedron Asymmetry 16:3682-3689

Kavanagh KL, Jornvall H, Persson B, Oppermann U (2008) Medium- and short-chain dehydrogenase/reductase gene and protein families: the SDR superfamily: functional and structural diversity within a family of metabolic and regulatory enzymes. Cell Mol Life Sci 65:3895-3906

Leuchs S, Greiner L (2011) Alcohol dehydrogenase from Lactobacillus brevis: a versatile robust catalyst for enantioselective transformations. Chem Biochem Eng Q 25:267-281

Li BJ, Li YX, Bai DM, Zhang X, Yang HY, Wang J, Liu G, Yue JJ, Ling Y, Zhou DS, Chen HP (2014) Whole-cell biotransformation systems for reduction of prochiral carbonyl compounds to chiral alcohol in Escherichia coli. Sci Rep 4:6750. doi:10.1038/srep06750

Li A, Ye L, Wu H, Yang X, Yu H (2015) Characterization of an excellent antiPrelog short-chain dehydrogenase/reductase EbSDR8 from Empedobacter brevis ZJUY-1401. J Mol Catal B Enzym 122:179-187

Liu X, Chen R, Yang Z, Wang J, Lin J, Wei D (2014) Characterization of a putative stereoselective oxidoreductase from Gluconobacter oxydans and its application in producing ethyl (R)-4-chloro-3-hydroxybutanoate ester. Mol Biotechnol 56:285-295

Luo X, Wang YJ, Zheng YG (2015) Cloning and characterization of a NADHdependent aldo-keto reductase from a newly isolated Kluyveromyces lactis XP1461. Enzym Microb Technol 77:68-77

Ma CW, Zhang L, Dai JY, Xiu ZL (2013) Characterization and cofactor binding mechanism of a novel NAD(P)H-dependent aldehyde reductase from Klebsiella pneumoniae DSM2026. J Microbiol Biotechnol 23:1699-1707

Masud U, Matsushita K, Theeragool G (2011) Molecular cloning and characterization of two inducible NAD(+)-adh genes encoding NAD(+)-dependent alcohol dehydrogenases from Acetobacter pasteurianus SKU1 108. J Biosci Bioeng 112:422-431

Montfort L, Frenette G, Sullivan R (2002) Sperm-zona pellucida interaction involves a carbonyl reductase activity in the hamster. Mol Reprod Dev 61:113-119

Musa MM, Phillips RS (2011) Recent advances in alcohol dehydrogenasecatalyzed asymmetric production of hydrophobic alcohols. Catal Sci Technol 1:1311

Nakajin S, Minamikawa N, Baker ME, Toyoshima S (1998) An NADPH-dependent reductase in neonatal pig testes that metabolizes androgens and xenobiotics. Biol Pharm Bull 21:1356-1360

Ni Y, Li CX, Zhang J, Shen ND, Bornscheuer UT, Xu JH (2011) Efficient reduction of ethyl 2-oxo-4-phenylbutyrate at $620 \mathrm{~g} / \mathrm{L}^{-1}$ by a bacterial reductase with broad substrate spectrum. Adv Synth Catal 353:1213-1217

Persson B, Kallberg Y (2013) Classification and nomenclature of the superfamily of short-chain dehydrogenases/reductases (SDRs). Chem Biol Interact 202:111-115
Persson B, Kallberg Y, Oppermann U, Jörnvall H (2003) Coenzyme-based functional assignments of short-chain dehydrogenases/reductases (SDRs). Chem Biol Interact 143-144:271-278

Qian XL, Pan J, Shen ND, Ju X, Zhang J, Xu JH (2014) Efficient production of ethyl (R)-2-hydroxy-4-phenylbutyrate using a cost-effective reductase expressed in Pichia pastoris. Biochem Eng J 91:72-77

Richter N, Hummel W (2011) Biochemical characterisation of a NADPHdependent carbonyl reductase from Neurospora crassa reducing alphaand beta-keto esters. Enzyme Microb Technol 48:472-479

Sengupta D, Naik D, Reddy AR (2015) Plant aldo-keto reductases (AKRs) as multi-tasking soldiers involved in diverse plant metabolic processes and stress defense: a structure-function update. J Plant Physiol 179:40-55

Singh A, Bhattacharyya MS, Banerjee UC (2009) Purification and characterization of carbonyl reductase from Geotrichum candidum. Process Biochem 44:986-991

Takeuchi M, Kishino S, Park S-B, Kitamura N, Ogawa J (2015) Characterization of hydroxy fatty acid dehydrogenase involved in polyunsaturated fatty acid saturation metabolism in Lactobacillus plantarum AKU 1009a. J Mol Catal B Enzym 117:7-12

Tang TX, Liu Y, Wu ZL (2014) Characterization of a robust anti-Prelog shortchain dehydrogenase/reductase ChKRED20 from Chryseobacterium sp. CA49. J Mol Catal B Enzym 105:82-88

Wang XT, Yue D-M, Zong MH, Lou WY (2013) Use of ionic liquid to significantly improve asymmetric reduction of ethyl acetoacetate catalyzed by Acetobacter sp. CCTCC M209061 cells. Ind Eng Chem Res 52:12550-12558

Wang YJ, Liu XQ, Luo X, Liu ZQ, Zheng YG (2015) Cloning, expression and enzymatic characterization of an aldo-keto reductase from Candida albicans XP1463. J Mol Catal B Enzym 122:44-50

Weckbecker A, Hummel W (2009) Cloning, expression, and characterization of an (R)-specific alcohol dehydrogenase from Lactobacillus kefir. Biocatal Biotransform 24:380-389

Wei P, Xu P, Wang XT, Lou WY, Zong MH (2015) Asymmetric reduction of ethyl acetoacetate catalyzed by immobilized Acetobacter sp CCTCC M209061 cells in hydrophilic ionic liquid hybrid system. Biotechnol Bioprocess Eng 20:324-332

Wei P, Liang J, Cheng J, Zong M-H, Lou W-Y (2016) Markedly improving asymmetric oxidation of 1-(4-methoxyphenyl) ethanol with Acetobacter sp CCTCC M209061 cells by adding deep eutectic solvent in a two-phase system. Microb Cell Fact 15:5

Xu Q, Xu X, Huang H, Li S (2015) Efficient synthesis of (R)-2-chloro-1-phenylethol using a yeast carbonyl reductase with broad substrate spectrum and 2-propanol as cosubstrate. Biochem Eng J 103:277-285

Ye Q, Yan M, Yao Z, Xu L, Cao H, Li Z, Chen Y, Li S, Bai J, Xiong J, Ying H, Ouyang $P$ (2009) A new member of the short-chain dehydrogenases/reductases superfamily: purification, characterization and substrate specificity of a recombinant carbonyl reductase from Pichia stipitis. Biores Technol 100:6022-6027

Zhang BB, Lou WY, Zong MH, Wu H (2008) Efficient synthesis of enantiopure (S)-4-(trimethylsilyl)-3-butyn-2-ol via asymmetric reduction of 4-(trimethylsilyl)-3-butyn-2-one with immobilized Candida parapsilosis CCTCC M203011 cells. J Mol Catal B Enzym 54:122-129

Zhang R, Geng Y, Xu Y, Zhang W, Wang S, Xiao R (2011) Carbonyl reductase SCRII from Candida parapsilosis catalyzes anti-Prelog reaction to (S)1-phenyl-1,2-ethanediol with absolute stereochemical selectivity. Biores Technol 102:483-489

Zhang Y, Ujor V, Wick M, Ezeji TC (2015) Identification, purification and characterization of furfural transforming enzymes from Clostridium beijerinckii NCIMB 8052. Anaerobe 33:124-131

Zheng YG, Yin HH, Yu DF, Chen X, Tang XL, Zhang XJ, Xue YP, Wang YJ, Liu ZQ (2017) Recent advances in biotechnological applications of alcohol dehydrogenases. Appl Microbiol Biotechnol 101:987-1001 